\title{
Dithiocarbonato nickel, palladium and platinum complexes bearing bis(diphenylphosphino)ferrocene: synthesis and X-ray structure determination
}

\author{
MOHAMMAD EL-KHATEEB ${ }^{\mathrm{a}, *}$, QUSAY TANASH ${ }^{\mathrm{a}}$, HASSAN ABUL-FUTOUH ${ }^{\mathrm{b}}$, \\ HELMAR GÖRLS ${ }^{\mathrm{c}}$ and WOLFGANG WEIGAND ${ }^{\mathrm{c}}$ \\ ${ }^{a}$ Chemistry Department, Jordan University of Science and Technology, Irbid 22110, Jordan \\ ${ }^{b}$ Department of Pharmacy, Al-Zaytoonah University of Jordan, P.O. Box 130, Amman 11733, Jordan \\ ${ }^{\mathrm{c}}$ Institut für Anorganische und Analytische Chemie, Friedrich-Schiller-Universität Jena, Humboldt Str. 8, \\ 07743 Jena, Germany \\ E-mail: kateeb@just.edu.jo
}

MS received 25 May 2019; revised 15 July 2019; accepted 16 July 2019

\begin{abstract}
The dithiocarbonato metal complexes $\mathrm{M}\left(\kappa^{2} S, S-\mathrm{S}_{2} \mathrm{CO}\right)\left(\kappa^{2} P, P-\mathrm{dppf}\right)\{\mathrm{M}=\mathrm{Ni}, \mathrm{Pd}, \mathrm{Pt} ; \mathrm{dppf}=$ bis(diphenylphosphino)ferrocene $\}$ are obtained from the reaction of the metal(II) complexes $\left[\mathrm{M}\left(\kappa^{2} S, S-\mathrm{S}_{2-}\right.\right.$ $\mathrm{COEt})_{2}$ ] with the dppf ligand or from the chloride substitution of $\mathrm{M}\left(\kappa^{2} P, P\right.$-dppf $) \mathrm{Cl}_{2}$ by the $O$-ethyldithiocabonato anion. These complexes are produced by $\mathrm{C}-\mathrm{O}$ bond cleavage by the $O$-ethyldithiocarbonato anion present in solution. These new complexes have been characterized by UV-Vis, NMR, IR spectroscopy and elemental analysis. The structures of the three complexes were further confirmed by single-crystal X-ray diffraction analysis.
\end{abstract}

Keywords. Dithiocarbonate; structure; synthesis; characterization.

\section{Introduction}

$O$-alkyldithiocarbonato ligands, known as xanthates, and their metal complexes have many uses such as metal-ore flotation, ${ }^{1-4}$ vulcanization of rubber, ${ }^{5}$ biological remediation, ${ }^{6}$ non-linear optical applications, ${ }^{7}$ synthetic precursors for the generation of metal sulfide nanoparticles, 8,9 as well as their investigation for possible use as therapeutic agents. ${ }^{10-13}$ The complex bis $(O$-ethyldithiocarbonato)platinum(II), named thioplatin, is found to have antitumor activity against a number of human tumor lines. ${ }^{13}$ Its antitumor activity on some human tumors was comparable to cisplatin, but with a significantly lower toxicity on kidneys, small intestines and white blood cells. ${ }^{14}$

Analogous complexes to thioplatin, of the formula $\left[\mathrm{Pt}\left(\kappa^{2} S, S-\mathrm{S}_{2} \mathrm{COR}\right)_{2}\right]$ containing different alkyl groups, were synthesized and their cytotoxic activity was tested against several human tumor lines. ${ }^{11,12}$ Complexes with short $n$-alkyl chains were found to display significantly higher activity than those with long chains. Complexes

*For correspondence derived from secondary xanthates are also more active than those derived from primary ones. ${ }^{11,12}$

The reactions of nickel, palladium or platinum salts with the $O$-alkyldithiocarbonato anions produced the $\operatorname{bis}(O$ alkyldithiocarbonato)metal(II) complexes in fairly high yields. ${ }^{14-19}$ The reaction of $\left[\mathrm{Ni}\left(\kappa^{2} S, S-\mathrm{S}_{2} \mathrm{COR}\right)_{2}\right]$ with excess triphenylphosphine produced the dithiocarbonato complex $\left[\mathrm{Ni}\left(\kappa^{2} S, S-\mathrm{S}_{2} \mathrm{CO}\right)\left(\mathrm{PPh}_{3}\right)_{2}\right] .^{20,21}$ The corresponding reaction with $\mathrm{PMePh}_{2}$ gave a six-coordinate complex $\left[\mathrm{Ni}\left(\kappa^{2} S, S-\mathrm{S}_{2} \mathrm{COEt}\right)_{2}\left(\mathrm{PMePh}_{2}\right)_{2}\right]$ with two chelated alkyldithiocarbonato ligands for the ethyl complex and a tetracoordinate one $\left[\mathrm{Ni}\left(\kappa^{2} S, S-\mathrm{S}_{2} \mathrm{COC}_{6} \mathrm{H}_{11}\right)\left(\kappa^{1} S-\mathrm{S}_{2}\right.\right.$ $\left.\left.\mathrm{COC}_{6} \mathrm{H}_{11}\right)\left(\mathrm{PMePh}_{2}\right)\right]$ with one bidentate and one monodentate alkyldithiocarbonato ligands for the cyclohexyl derivative. $^{22}$ The strong chelate ligand bis(diphenylphosphino)ethane (dppe) reacted with $\left[\mathrm{Ni}\left(\kappa^{2} S, S-\mathrm{S}_{2} \mathrm{COEt}\right)_{2}\right]$ forming an equilibrium mixture of five-coordinate complex $\left[\mathrm{Ni}\left(\kappa^{2} S, S-\mathrm{S}_{2} \mathrm{COEt}\right)\left(\kappa^{1} S\right.\right.$-S $\left.\mathrm{S}_{2} \mathrm{COEt}\right)\left(\kappa^{2} P, P\right.$-dppe $\left.)\right]$ and a six-coordinate one $\left[\mathrm{Ni}\left(\kappa^{2} S, S-\mathrm{S}_{2} \mathrm{COEt}\right)_{2}\left(\kappa^{2} P, P\right.\right.$-dppe $\left.)\right]$. However, the cyclohexyl derivative reacted with excess dppe forming the dithiocarbonato complex $\mathrm{Ni}\left(\kappa^{2} S, S-\mathrm{S}_{2-}\right.$ CO) $\left(\kappa^{2} P, P\right.$-dppe $) .^{23,24}$ In another study, the complexes $\left[\mathrm{Ni}\left(\kappa^{2} S, S-\mathrm{S}_{2} \mathrm{COR}\right)_{2}\right](\mathrm{R}=\mathrm{Me}, \mathrm{Et})$ reacted with dppe to produce products depending on the reaction's conditions. 
The 1:2 metal to ligand ratio-reaction gave the trimer $\left[\mathrm{Ni}_{3}(\mu-\mathrm{S})_{2}\left(\kappa^{2} S, S-\mathrm{SCOR}\right)_{2}(\mathrm{dppe})\right]$ if the reaction is carried out at room temperature. However, the 1:1 molar ratioreaction gave the dithiocarbonato complex $\left[\mathrm{Ni}\left(\kappa^{2} S, S-\mathrm{S}_{2-}\right.\right.$ $\mathrm{CO})\left(\kappa^{2} P, P\right.$-dppe $) .^{24}$ The reaction of $\left[\left(\kappa^{2} P, P\right.\right.$-dippe $)$ $\mathrm{NiBr}_{2}$ ] with $\mathrm{ROCS}_{2}^{-}(\mathrm{R}=\mathrm{Me}, \mathrm{Et}, \mathrm{Pr})$ gave the dithiocarbonato complex $\left[\mathrm{Ni}\left(\kappa^{2}-S, S-\mathrm{S}_{2} \mathrm{CO}\right)\left(\kappa^{2} P, P\right.\right.$-dippe $\left.)\right]{ }^{25}$

The interaction of bis $(O$-alkyldithiocarbonato)platinum(II) with phosphine ligands has been studied by NMR spectroscopy. ${ }^{26,27}$ The reaction of $\left[\mathrm{Pt}\left(\kappa^{2} S, S-\mathrm{S}_{2} \mathrm{COR}\right)_{2}\right]$ $\left(\mathrm{R}=\mathrm{Et}, \mathrm{Pr}^{n}, \mathrm{CH}_{2} \mathrm{Ph}\right)$ with $\mathrm{PPh}_{3}$ occurred by stepwise cleavage of metal-sulfur bonds to generate four-coordinate compounds $\left[\operatorname{Pt}\left(\kappa^{2} S, S-\mathrm{S}_{2} \mathrm{COR}\right)\left(\kappa^{1} S-\mathrm{S}_{2} \mathrm{COR}\right)\left(\mathrm{PPh}_{3}\right)\right]$ with unidentate/bidentate dithiocarbonates and $\left[\operatorname{Pt}\left(\kappa^{2} S, S-S_{2-}\right.\right.$ $\left.\mathrm{COR})\left(\mathrm{PPh}_{3}\right)_{2}\right]\left[\mathrm{S}_{2} \mathrm{COR}\right]$ with ionic/bidentate coordination of the sulfur ligands. In addition, a further nucleophilic attack can occur in the OR group to give the dithiocarbonato complex $\left[\mathrm{Pt}\left(\kappa^{2} S, S-\mathrm{S}_{2} \mathrm{CO}\right)\left(\mathrm{PPh}_{3}\right)_{2}\right] .{ }^{27}$ The interaction of bis(n-propyldithiocarbonato)platinum with several bidentate ligands $\left\{\mathrm{P}-\mathrm{P}=\mathrm{Ph}_{2} \mathrm{PCH}_{2} \mathrm{CH}_{2} \mathrm{PPh}_{2}\right.$, (dppe), $\mathrm{Ph}_{2}$ $\mathrm{PCH}_{2} \mathrm{PPh}_{2}$ (dppm), $\mathrm{Ph}_{2} \mathrm{AsCH}_{2} \mathrm{CH}_{2} \mathrm{PPh}_{2}$ (ape), $\mathrm{Ph}_{2}$ $\mathrm{P}(\mathrm{S}) \mathrm{CH}_{2} \mathrm{PPh}_{2}$, (dppmS), $\mathrm{Ph}_{2} \mathrm{P}(\mathrm{Se}) \mathrm{CH}_{2} \mathrm{PPh}_{2}$ (dppmSe) $\}$ is reported. ${ }^{26}$ When 1:1 molar reaction of $\left[\operatorname{Pt}\left(\kappa^{2} S, S-S_{2-}\right.\right.$ $\left.\mathrm{COPr}^{n}\right)_{2}$ ] with P-P is carried out at room temperature, one $n$-propyldithiocarbonato ligand is often displaced to give $\left[\operatorname{Pt}\left(\kappa^{2} S, S-\mathrm{S}_{2} \mathrm{COPr}^{n}\right)\left(\kappa^{2} P, P \text {-P-P }\right)\right]^{+}$which hydrolyzes to give the dithiocarbonato complex $\left[\mathrm{Pt}\left(\kappa^{2} S, S-\mathrm{S}_{2} \mathrm{CO}\right)\left(\kappa^{2-}\right.\right.$ $P, P$-P-P)] and the xanthate ester. If the same reaction is carried out at a low temperature, a different mechanism is observed. First, a complex with monodentate bis(phosphine), mono- and bidentate $n$-propyldithicarbonate is obtained. Then the latter complex lost a propyldithiocarbonato ligand to form a complex with both bis(phosphine) and $n$-propyldithiocarbonato ligands. At low temperature, the hydrolysis reaction is avoided. ${ }^{27}$

In this report, the interaction of the $\operatorname{bis}(O-$ ethyldithiocarboanto)metal complexes $(\mathrm{Ni}, \mathrm{Pd}, \mathrm{Pt})$ with $1,1^{\prime}$-bis(diphenylphosphino)ferrocene ligand is described. The molecular structures of the generated complexes are determined.

\section{Experimental}

\subsection{General}

Reactions and manipulations were done under atmospheric condition and normal solvents unless stated otherwise. The following chemicals were used as received (Sigma/ Aldrich): potassium $O$-ethyldithiocarbonate, $1,1^{\prime}$ bis(diphenylphosphino)ferrocene (dppf), nickel(II) bromide, palladium(II) chloride, potassium tetrachloroplatinate. The following solvents are also used as received (Acros): chloroform, dichloromethane, ethanol, hexane, diethyl ether and tetrahydrofuran. The complexes $\mathrm{M}\left(\kappa^{2} S, S-\mathrm{S}_{2-}\right.$ $\mathrm{COEt})_{2}{ }^{12,13,16}$ and $\mathrm{M}\left(\kappa^{2} P, P\right.$-dppf $) \mathrm{X}_{2}{ }^{28-30}(\mathrm{M}=\mathrm{Ni}, \mathrm{Pd}, \mathrm{Pt})$ were prepared by literature methods.

Infrared (IR) spectra were recorded on a Bruker alpha FT-IR spectrometer equipped with ATR unit. Nuclear magnetic resonance (NMR) spectra were recorded on a Bruker-Avance $400 \mathrm{MHz}$ spectrometer. Chemical shift values are given in ppm and are referenced to $\mathrm{SiMe}_{4}$ or $\mathrm{CHCl}_{3}\left({ }^{1} \mathrm{H},{ }^{13} \mathrm{C}\left\{{ }^{1} \mathrm{H}\right\}\right)$, external $\mathrm{H}_{3} \mathrm{PO}_{4}$ for ${ }^{31} \mathrm{P}\left\{{ }^{1} \mathrm{H}\right\}$ and to $\mathrm{K}_{2} \mathrm{PtCl}_{4}$ for ${ }^{195} \mathrm{Pt}\left\{{ }^{1} \mathrm{H}\right\}$-NMR. Elemental analyses were performed by CHNS and $\mathrm{O}$ Thermo Scientific 2000 instrument. The UV-Vis data were collected using a Shimadzu instrument.

\subsection{General Procedure for the Preparation of $M\left(\kappa^{2} S, S-S_{2} C O\right)\left(\kappa^{2} P, P-d p p f\right)$}

\section{Method A}

A mixture of $\mathrm{M}\left(\kappa^{2} P, P\right.$-dppf $) \mathrm{X}_{2}(1.00 \mathrm{mmol})$ and $\mathrm{EtOCS}_{2} \mathrm{~K}$ $(0.320 \mathrm{~g}, 2.00 \mathrm{mmol})$ in $50 \mathrm{~mL}$ of tetrahydrofuran is stirred for one hour at room temperature. The solution's color lightened and a precipitate is formed. The solution is filtered and the volatiles of the filtrate are removed under vacuum. The resulting solid was recrystallized from $\mathrm{CH}_{2} \mathrm{Cl}_{2} /$ hexane at $4{ }^{\circ} \mathrm{C}$.

\section{Method B}

To a chloroform solution $(50 \mathrm{~mL})$ of $\mathrm{M}\left(\kappa^{2} S, S-\mathrm{S}_{2} \mathrm{COEt}\right)_{2}$ $(1.00 \mathrm{mmol})$, bis(diphenylphosphino)ferrocene $(0.554 \mathrm{~g}$, $1.00 \mathrm{mmol}$ ) is added. The mixture is stirred at room temperature for one hour. The volatiles were removed under vacuum leaving a brown-orange solid. The solid was extracted by $3 \times 5 \mathrm{~mL}$ dichloromethane and filtered. The volatiles of the filtrate were removed under vacuum. The resulting solid was recrystallized from $\mathrm{CH}_{2} \mathrm{Cl}_{2} /$ hexane at $4{ }^{\circ} \mathrm{C}$.

2.2a $\mathrm{Ni}\left(\kappa^{2} \mathrm{~S}, \mathrm{~S}-\mathrm{S}_{2} \mathrm{CO}\right)\left(\kappa^{2} P, P-\left(\mathrm{PPh}_{2} \mathrm{C}_{5} \mathrm{H}_{4}\right)_{2} \mathrm{Fe}\right) \quad(\mathrm{I})$ : Yield: $60 \%$. Brown. IR $\left(\mathrm{KBr}, \mathrm{cm}^{-1}\right): \mathrm{v}(\mathrm{SC}=\mathrm{O}) 1659 .{ }^{1} \mathrm{H} \mathrm{NMR}$ $\left(400 \mathrm{MHz}, \mathrm{CDCl}_{3}\right) \delta 4.20\left(\mathrm{bs}, 4 \mathrm{H}, \mathrm{C}_{5} \mathrm{H}_{4}\right), 4.29$ (bs, $4 \mathrm{H}$, $\left.\mathrm{C}_{5} \mathrm{H}_{4}\right), 7.44(\mathrm{~m}, 12 \mathrm{H}, \mathrm{Ph}), 7.70(\mathrm{~m}, 8 \mathrm{H}, \mathrm{Ph}) .{ }^{13} \mathrm{C}\left\{{ }^{1} \mathrm{H}\right\}$ NMR $\left(100 \mathrm{MHz}, \mathrm{CDCl}_{3}\right) \delta 73.43-77.16 \mathrm{Cp}, 128.48-135.56 \mathrm{Ph}$, $193.71 \mathrm{C}=\mathrm{O} .{ }^{31} \mathrm{P}\left\{{ }^{1} \mathrm{H}\right\}$ NMR $\left(161.5 \mathrm{MHz}, \mathrm{CDCl}_{3}\right) \delta 30.95$. UV-Vis $\left(\mathrm{CH}_{2} \mathrm{Cl}_{2}, \lambda_{\max }, \mathrm{nm}\right) 252,300,380$. Anal. Calc. for $\mathrm{C}_{35} \mathrm{H}_{28} \mathrm{FeNiOP}_{2} \mathrm{~S}_{2}$ (1) C, 59.61; H, 4.00; S, 9.09\% Found: C, 58.95; H, 3.85; S, 8.47\%.

2.2b $P d\left(\kappa^{2} S, S-S_{2} C O\right)\left(\kappa^{2} P, P-\left(P P h_{2} C_{5} H_{4}\right)_{2} F e\right)$ (2): Yield: $80 \%$. Yellow. IR $\left(\mathrm{KBr}, \mathrm{cm}^{-1}\right): \mathrm{v}(\mathrm{SC}=\mathrm{O}) 1678 .{ }^{1} \mathrm{H}$ NMR $\left(400 \mathrm{MHz}, \mathrm{CDCl}_{3}\right) \delta 4.19\left(\mathrm{~d}, 2 \mathrm{H}, \mathrm{C}_{5} \mathrm{H}_{4} J_{H H}=4.0 \mathrm{~Hz}\right), 4.30$ $\left(\mathrm{d}, 2 \mathrm{H}, \mathrm{C}_{5} \mathrm{H}_{4} J_{H H}=4.0 \mathrm{~Hz}\right), 4.39\left(\mathrm{~d}, 2 \mathrm{H}, \mathrm{C}_{5} \mathrm{H}_{4} J_{H H}=4.0 \mathrm{~Hz}\right)$, $4.41\left(\mathrm{~d}, 2 \mathrm{H}, \mathrm{C}_{5} \mathrm{H}_{4} J_{H H}=4.0 \mathrm{~Hz}\right), 7.42(\mathrm{~m}, 12 \mathrm{H}, \mathrm{Ph}), 7.78$ $(\mathrm{m}, \quad 8 \mathrm{H}, \mathrm{Ph}) .{ }^{13} \mathrm{C}\left\{{ }^{1} \mathrm{H}\right\} \quad \mathrm{NMR}\left(100 \mathrm{MHz}, \mathrm{CDCl}_{3}\right) \delta$ 73.25-75.99 Cp, 128.22-135.22 Ph, 197.04 C=O. ${ }^{31} \mathrm{P}\left\{{ }^{1} \mathrm{H}\right\}$ NMR $\left(161.5 \mathrm{MHz}, \mathrm{CDCl}_{3}\right) \delta$ 29.26, 35.53. UV-Vis 
$\left(\mathrm{CH}_{2} \mathrm{Cl}_{2}, \lambda_{\max }, \mathrm{nm}\right) 252,304,378$. Anal. Calc. for $\mathrm{C}_{35-}$ $\mathrm{H}_{28} \mathrm{FeOP}_{2} \mathrm{PdS}_{2}$ (2) $\mathrm{C}, 55.83 ; \mathrm{H}, 3.75 ; \mathrm{S}, 8.52 \%$. Found: $\mathrm{C}$, 55.16 ; H, 3.55; S, $8.36 \%$.

2.2c $P t\left(\kappa^{2} S, S-S_{2} C O\right)\left(\kappa^{2} P, P-\left(P P h_{2} C_{5} H_{4}\right)_{2} F e\right) \quad(3)$ : Yield: $80 \%$. Orange. IR $\left(\mathrm{KBr}, \mathrm{cm}^{-1}\right): \mathrm{v}(\mathrm{SC}=\mathrm{O}) 1685 .{ }^{1} \mathrm{H} \mathrm{NMR}$ $\left(400 \mathrm{MHz}, \mathrm{CDCl}_{3}\right) \delta 4.21\left(\mathrm{~d}, 2 \mathrm{H}, \mathrm{C}_{5} \mathrm{H}_{4} J_{H H}=5.0 \mathrm{~Hz}\right) ; 4.22$ $\left(\mathrm{d}, 2 \mathrm{H}, \mathrm{C}_{5} \mathrm{H}_{4} J_{H H}=5.0 \mathrm{~Hz}\right) ; 4.40\left(\mathrm{~d}, 2 \mathrm{H}, \mathrm{C}_{5} \mathrm{H}_{4} J_{H H}=6.0\right.$ on the ethyl carbon resulting into a $\mathrm{C}-\mathrm{O}$ bond cleavage forming complexes $\mathbf{1 - 3}$ and the xanthate ester (Scheme 1).

Complexes 1-3 were also obtained from the reactions of $\mathrm{M}\left(\kappa^{2} P, P\right.$-dppf $) \mathrm{Cl}_{2}$ with the $O$-ethylditiocarbonato anion as shown in Equation 1.

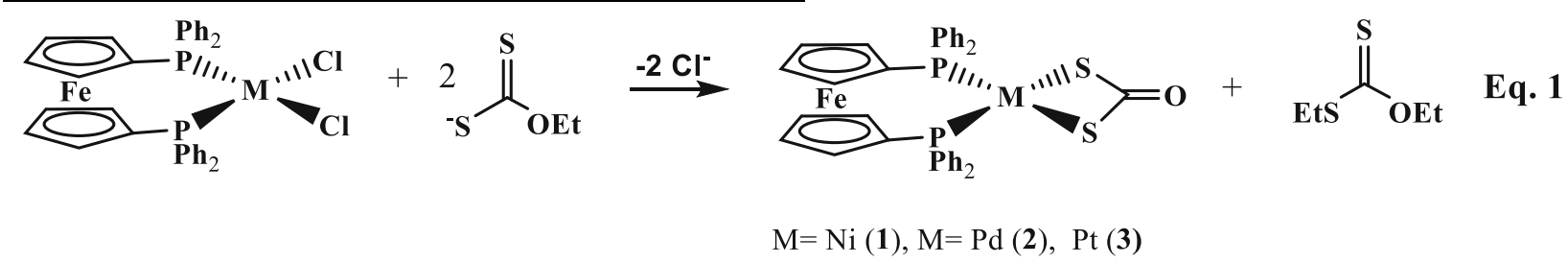

$\mathrm{Hz}) ; 4.42\left(\mathrm{~d}, 2 \mathrm{H}, \mathrm{C}_{5} \mathrm{H}_{4} J_{H H}=6.0 \mathrm{~Hz}\right) ; 7.33-7.89(\mathrm{~m}, 20 \mathrm{H}$, $\mathrm{Ph}) .{ }^{13} \mathrm{C}\left\{{ }^{1} \mathrm{H}\right\}$ NMR $\left(100 \mathrm{MHz}, \mathrm{CDCl}_{3}\right) \delta 73.33-75.94 \mathrm{Cp}$, 128.03-135.15 Ph, 204.52 C=O. ${ }^{31} \mathrm{P}\left\{{ }^{1} \mathrm{H}\right\}$ NMR $(161.5$ $\left.\mathrm{MHz}, \mathrm{CDCl}_{3}\right) \delta 12.80\left(J_{\mathrm{Pt}-\mathrm{P}}=3767 \mathrm{~Hz}\right), 15.24\left(J_{\mathrm{Pt}-\mathrm{P}}=3242\right.$ $\mathrm{Hz}) .{ }^{135} \mathrm{Pt}\left\{{ }^{1} \mathrm{H}\right\}$ NMR $\left(86.0 \mathrm{MHz}, \mathrm{CDCl}_{3}\right) \delta-4379.33\left(J_{\mathrm{Pt}-}\right.$ $\left.{ }_{\mathrm{P}}=3810 \mathrm{~Hz}\right)$. UV-Vis $\left(\mathrm{CH}_{2} \mathrm{Cl}_{2}, \lambda_{\max }, \mathrm{nm}\right) 256,308,780$. Anal. Calc. for $\mathrm{C}_{35} \mathrm{H}_{28} \mathrm{FeOP}_{2} \mathrm{PtS}_{2}$ (3) C, 49.95; H, 3.35; S, 7.62\%. Found: C, 49.34; H, 3.12; S, $6.87 \%$.

\subsection{X-ray crystal structure analysis}

The intensity data for the compounds were collected on a Nonius Kappa CCD diffractometer using graphitemonochromated Mo- $\mathrm{K}_{\alpha}$ radiation. Data were corrected for Lorentz and polarization effects; absorption was taken into account on a semi-empirical basis using multiple-scans. ${ }^{31-35}$

The structures were solved by direct methods $\left(\right.$ SHELXS) ${ }^{34}$ and refined by full-matrix least squares techniques against $\mathrm{Fo}^{2}$ (SHELXL-97). ${ }^{34}$ All hydrogen atoms were located by difference Fourier synthesis and refined isotropically. All non-disordered, non-hydrogen atoms were refined anisotropically. ${ }^{34}$ Crystallographic data, as well as structure solution and refinement details, are summarized in Table 1. XP was used for structure representations. ${ }^{35}$

\section{Results and Discussion}

\subsection{Synthesis}

Treatment of $\left[\mathrm{M}\left(\kappa^{2} S, S-\mathrm{S}_{2} \mathrm{COEt}\right)_{2}\right]$ with $1,1^{\prime}$ bis(diphenylphosphino)ferrocene (dppf) gave [M $\left(\kappa^{2} S, S\right.$ $\left.\left.\mathrm{S}_{2} \mathrm{CO}\right)\left(\kappa^{2} P, P-\left(\mathrm{PPh}_{2} \mathrm{C}_{5} \mathrm{H}_{4}\right)_{2} \mathrm{Fe}\right)\right](\mathrm{M}=\mathrm{Ni}(\mathbf{1}), \mathrm{Pd}(2), \mathrm{Pt}$ (3)) instead of the expected products $\left[\mathrm{M}\left(\kappa^{2} S, S-\mathrm{S}_{2-}\right.\right.$ $\left.\mathrm{COEt})\left(\kappa^{2} P, P-\left(\mathrm{PPh}_{2} \mathrm{C}_{5} \mathrm{H}_{4}\right)_{2} \mathrm{Fe}\right)\right]^{+} \quad$ (Scheme 1$)$. Complexes 1-3 resulted from the latter cationic complexes by the attack of the dithiocarbonato anion
Complexes 1-3 have different colors depending on the metal content, the nickel complex is brown, the palladium complex is yellow while the platinum complex is orange. They are soluble in polar organic solvents such as chlorinated solvents, alcohols and insoluble in hydrocarbon solvents and diethyl ether. The complexes were identified based on their IR, ${ }^{1} \mathrm{H}-$, ${ }^{13} \mathrm{C}\left\{{ }^{1} \mathrm{H}\right\}-,{ }^{31} \mathrm{P}\left\{{ }^{1} \mathrm{H}\right\}-\mathrm{NMR}$ spectroscopy and elemental analysis. The ${ }^{1} \mathrm{H}-\mathrm{NMR}$ spectrum of $\mathbf{1}$ showed the protons of the cyclopentadienyl ferrocene moiety as two signals at 4.20 and $4.29 \mathrm{ppm}$ which are attributed to $\alpha$ and $\beta$ protons of the $C p$-ring. These bands are shifted to low field compared to those of the ( $\kappa^{2} P, P$-dppf) $\mathrm{NiCl}_{2}$ $(4.02,4.27 \mathrm{ppm}) .{ }^{16}$ The same protons of $\mathbf{2}$ and $\mathbf{3}$ are shown as four doublets (2: 4.19, 4.30, 4.39, $4.41 \mathrm{ppm}$. 3: $4.21,4.22,4.40,4.42 \mathrm{ppm}$ ) due to possible deviation from coplanarity of the phosphorous atoms relative to their $\mathrm{Cp}$-rings. These ranges are similar to those of $\left(\kappa^{2} P, P\right.$-dppf $) \mathrm{M}\left(\mathrm{SC}_{7} \mathrm{H}_{4} \mathrm{OS}\right)_{2}$ while their splitting is different as the latter complexes showed only two multiplets. ${ }^{36}$ The protons of the phenyl groups of the dppf ligand are shown in the spectra as multiplets in the aromatic region with the expected integrations.

Complexes $\left[\mathrm{M}\left(\kappa^{2} S, S-\mathrm{S}_{2} \mathrm{CO}\right)\left(\kappa^{2} P, P-\left(\mathrm{PPh}_{2} \mathrm{C}_{5} \mathrm{H}_{4}\right){ }_{2} \mathrm{Fe}\right)\right]$ (1-3) were also characterized by ${ }^{13} \mathrm{C}\left\{{ }^{1} \mathrm{H}\right\}$ NMR spectroscopy and their spectra showed peaks in the range of 73.43-78.11 ppm for the Cp-rings of ferrocene and peaks in the range of 128.45-135.37 ppm for the phenyl groups. The carbonyl carbon of these complexes are shown as a weak band (1: 193.71, 2: 197.04, 3: 204.52 ppm). The ${ }^{195} \mathrm{Pt}\left\{{ }^{1} \mathrm{H}\right\}$ NMR spectrum of $\mathbf{3}$ displayed a triplet at $-4379.33 \mathrm{ppm}$ with a Pt-P coupling of 3810 Hz. The chemical shift and the coupling constant are within the range observed for phosphine platinum dichalcogenate complexes. ${ }^{37}$ 
Table 1. Crystal data and refinement details for the X-ray structure determinations of 1-3.

\begin{tabular}{|c|c|c|c|}
\hline Compound & 1 & 2 & 3 \\
\hline $\begin{array}{l}\text { Formula } \\
\text { fw }\left(\mathrm{g} \bullet \mathrm{mol}^{-1}\right)\end{array}$ & $\begin{array}{c}\mathrm{C}_{35.75} \mathrm{H}_{29.75} \mathrm{FeNiOP}_{2} \mathrm{~S}_{2} \\
715.97\end{array}$ & $\begin{array}{c}\mathrm{C}_{35} \mathrm{H}_{28} \mathrm{FeOP}_{2} \mathrm{PdS}_{2} \\
752.88\end{array}$ & $\begin{array}{c}\mathrm{C}_{35} \mathrm{H}_{28} \mathrm{FeOP}_{2} \mathrm{PtS}_{2} \\
841.57\end{array}$ \\
\hline $\mathrm{T} /{ }^{\circ} \mathrm{C}$ & $-140(2)$ & $-140(2)$ & $-140(2)$ \\
\hline Crystal system & Triclinic & Orthorhombic & Orthorhombic \\
\hline Space group & $\mathrm{P} \overline{1}$ & C $2222_{1}$ & C $2222_{1}$ \\
\hline a) $\AA$ & $10.9109(2)$ & $11.1196(3)$ & $11.1215(2)$ \\
\hline$b / \AA$ & $15.7089(2)$ & $18.4399(5)$ & $18.4468(3)$ \\
\hline$c / \AA$ & $21.0838(3)$ & 14.6191(3) & $14.5793(3)$ \\
\hline$\alpha /^{\circ}$ & $108.831(1)$ & 90 & 90 \\
\hline$\beta 1^{\circ}$ & $92.040(1)$ & 90 & 90 \\
\hline$\gamma /{ }^{\circ}$ & $106.096(1)$ & 90 & 90 \\
\hline$V / \AA^{3}$ & $3254.98(9)$ & $2997.56(13)$ & $2991.03(10)$ \\
\hline$Z$ & 4 & 4 & 4 \\
\hline$\rho\left(\mathrm{g} \bullet \mathrm{cm}^{-3}\right)$ & 1.461 & 1.668 & 1.869 \\
\hline$\mu\left(\mathrm{cm}^{-1}\right)$ & 12.79 & 13.59 & 54.33 \\
\hline Measured data & 25466 & 13541 & 18474 \\
\hline Data with $\mathrm{I}>2 \sigma(\mathrm{I})$ & 12619 & 3269 & 3218 \\
\hline Unique data $\left(\mathrm{R}_{\text {int }}\right)$ & $14742 / 0.0300$ & $3433 / 0.0332$ & $3432 / 0.0538$ \\
\hline $\mathrm{w} R_{2}\left(\text { all data, on } \mathrm{F}^{2}\right)^{\mathrm{a})}$ & 0.0947 & 0.0484 & 0.0483 \\
\hline$R_{1}(I>2 \sigma(I))^{\mathrm{a})}$ & 0.0460 & 0.0255 & 0.0243 \\
\hline & 1.092 & 1.044 & 1.101 \\
\hline Res. dens./e $\bullet \AA^{-3}$ & $1.013 /-0.631$ & $0.309 /-0.291$ & $0.399 /-0.603$ \\
\hline Flack-parameter & - & $0.44(2)$ & $0.032(6)$ \\
\hline Absorpt method & Multi-scan & Multi-scan & Multi-scan \\
\hline Absorpt corr $\mathrm{T}_{\min } / \max$ & $0.6901 / 0.7456$ & $0.7064 / 0.7456$ & $0.6201 / 0.7456$ \\
\hline CCDC No. & 1916199 & 1916200 & 1916481 \\
\hline
\end{tabular}

a) Definition of the $R$ indices: $\mathrm{R}_{1}=\left(\Sigma|| F_{\mathrm{o}}|-| F_{\mathrm{c}}||\right) / \Sigma\left|F_{\mathrm{o}}\right|$; $\mathrm{wR}_{2}=\left\{\Sigma\left[w\left(F_{\mathrm{o}}^{2}-F_{\mathrm{c}}^{2}\right)^{2}\right] / \Sigma\left[w\left(F_{\mathrm{o}}^{2}\right)^{2}\right]\right\}^{1 / 2}$ with $w^{-1}=\sigma^{2}\left(F_{\mathrm{o}}^{2}\right)+(a P)^{2}+\mathrm{bP} ; \mathrm{P}=\left[2 \mathrm{~F}_{\mathrm{c}}^{2}+\operatorname{Max}\left(\mathrm{F}_{\mathrm{O}}^{2}\right] / 3 ;\right.$ b) $s=\left\{\Sigma\left[w\left(F_{\mathrm{o}}^{2}-F_{\mathrm{c}}^{2}\right)^{2}\right] /\left(N_{\mathrm{o}}-N_{\mathrm{p}}\right)\right\}^{1 / 2}$.
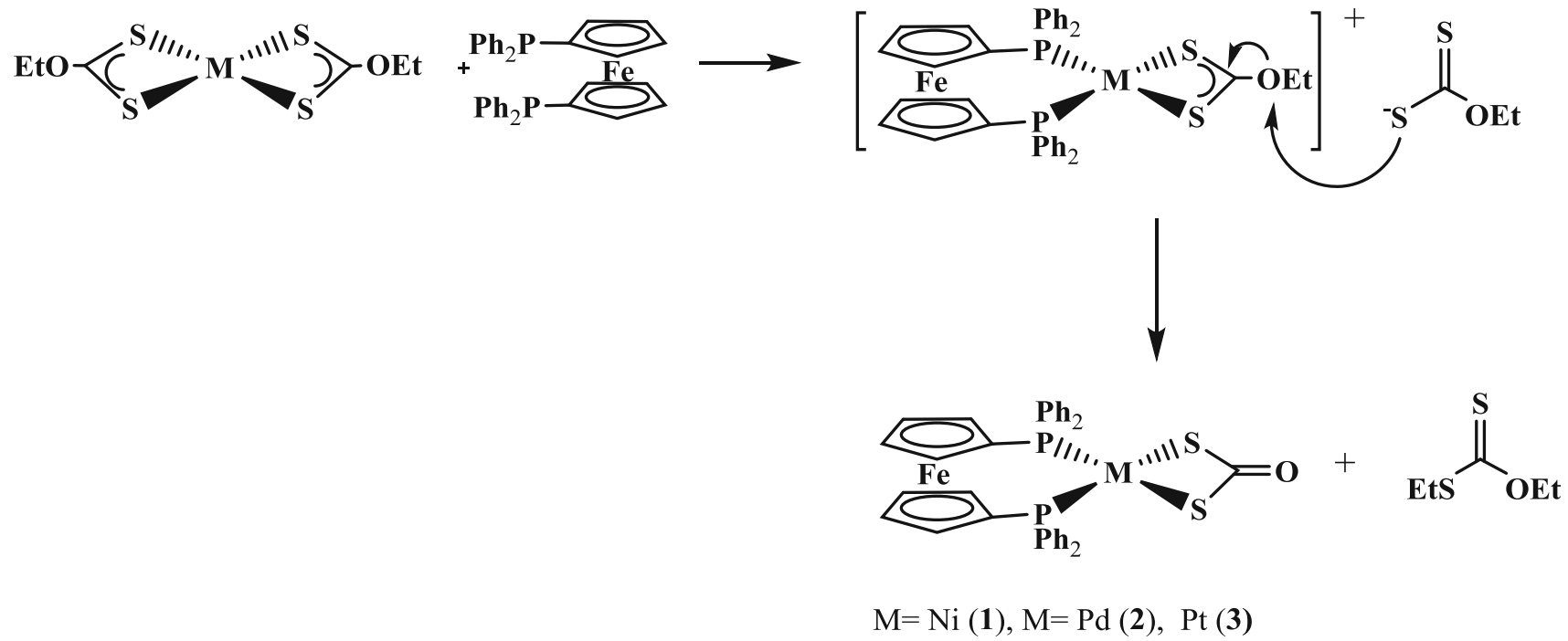

Scheme 1. Synthesis of the $\left\{1,1^{\prime}\right.$-bis(diphenylphosphino)ferrocene(dithiocarboante) $\}$ metal complexes 1-3.

The ${ }^{31} \mathrm{P}\left\{{ }^{1} \mathrm{H}\right\}$ NMR spectrum of $\mathbf{1}$ presented a singlet at $30.95 \mathrm{ppm}$ for the two equivalent phosphorous atoms which is comparable to that of $\left(\kappa^{2} P, P\right.$-dppf $) \mathrm{NiCl}_{2}$ (28.39 ppm). However, the two phosphorous atoms of $\mathbf{2}$ and of $\mathbf{3}$ are not equivalent since the two phosphorous atoms deviate from coplanarity with the Cp-rings. For 2, two singlets at 29.26 and $35.53 \mathrm{ppm}$ are observed while those of $\mathbf{3}$ 
are observed at 12.80 and $15.24 \mathrm{ppm}$ each with a platinum satellite with the platinum-phosphorous coupling of 3767 and $3242 \mathrm{~Hz}$, respectively. These values are comparable to those of $\left(\kappa^{2} P, P\right.$ dppf)M $\left(\mathrm{SC}_{7} \mathrm{H}_{4} \mathrm{OS}\right) \quad(\mathrm{M}=\mathrm{Pd}: 28.5 \mathrm{ppm} ; \mathrm{Pt}: 16.5$ $\mathrm{ppm})^{36}$ and differ from those of $\left(\kappa^{2} P, P\right.$-dppf $) \mathrm{MCl}_{2}$ (M= Pd: 34.0 ppm; $\left.{ }^{38} \mathrm{Pt}: 11.15 \mathrm{ppm}\right) .{ }^{39}$

The IR spectra of complexes 1-3 present a medium peak in the range of 1676 to $1689 \mathrm{~cm}^{-1}$ for the carbonyl group of the dithiocarbonato ligand. This range is similar to those reported for similar systems $\left[\mathrm{M}\left(\kappa^{2} S, S-\mathrm{S}_{2} \mathrm{CO}\right)(\mathrm{L})_{2}\right]\left(\mathrm{L}_{2}=\left(\mathrm{PPh}_{3}\right)_{2}, \mathrm{dppe}\right) .^{23,24}$

\subsection{Molecular structure determination}

Crystals of each of complexes 1-3 suitable for structure determination are grown by layering hexane over a dichloromethane solution of them. Their structures are shown in Figures 1, 2, 3, respectively. Selected bond lengths and angles of these complexes are presented in Table 2.

The Ni-S bond lengths of 1 (2.1785(8), 2.2081(9) $\AA$ ) are shorter than those of the corresponding lengths of $\left[\mathrm{Ni}\left(\kappa^{2} S, S-\mathrm{S}_{2} \mathrm{CO}\right)\left(\kappa^{2} P, P-\left(\mathrm{Ph}_{2} \mathrm{PC}_{2} \mathrm{H}_{4} \mathrm{PPh}_{2}\right)\right](2.197(1)\right.$, 2.207(1) $\AA$ ). Consequently, the Ni-P bond distance of 1 (2.2006(8), 2.2041(8) $\AA$ ) are longer than that of $\left[\mathrm{Ni}\left(\kappa^{2} S, S-\mathrm{S}_{2} \mathrm{CO}\right)\left(\kappa^{2} P, P-\left(\mathrm{Ph}_{2} \mathrm{PC}_{2} \mathrm{H}_{4} \mathrm{PPh}_{2}\right)\right] \quad(2.165(1)\right.$, $2.162(2) \AA) .{ }^{40}$ For 2 , the Pd-S (2.3299(7) $\AA$ ) and Pd-P $(2.3121(7) \AA)$ bond distances are equivalent to the corresponding distances of $\mathrm{Pd}\left(\kappa^{2} S, S-\mathrm{S}_{2} \mathrm{CO}\right)\left(\mathrm{PPh}_{3}\right)_{2}$ (Pd-S: 2.340(4), 2.324(3) ^, Pd-P: 2.303(3), 2.337(3) $\AA) .{ }^{41}$ In a similar manner, the Pt-S $(2.3369(10) \AA)$ and

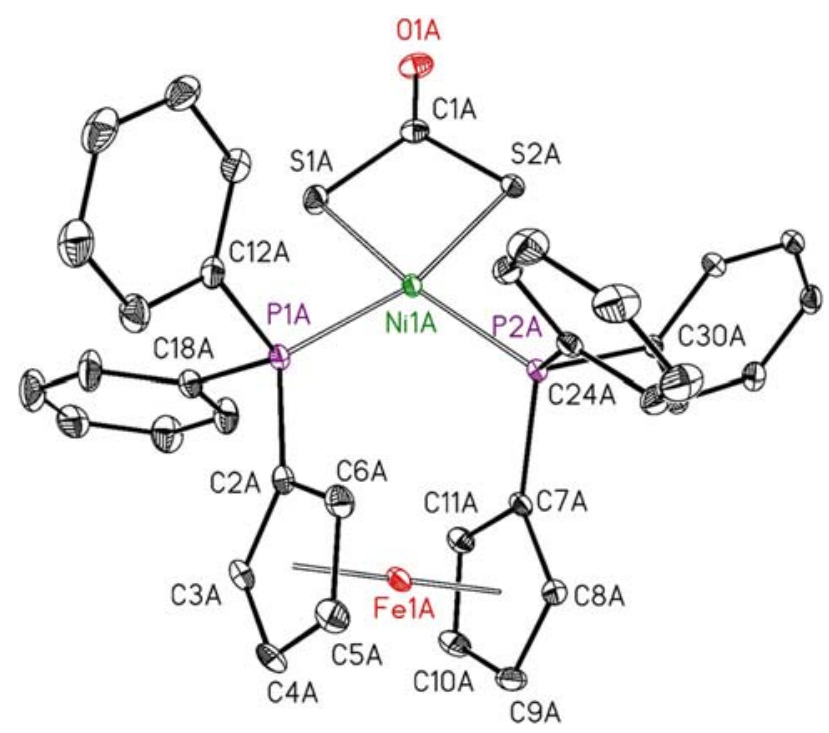

Figure 1. Molecular structure and atom labelling scheme of $\mathbf{1}$. The ellipsoids represent a probability of $30 \%, \mathrm{H}$ atoms are omitted for clarity reasons.

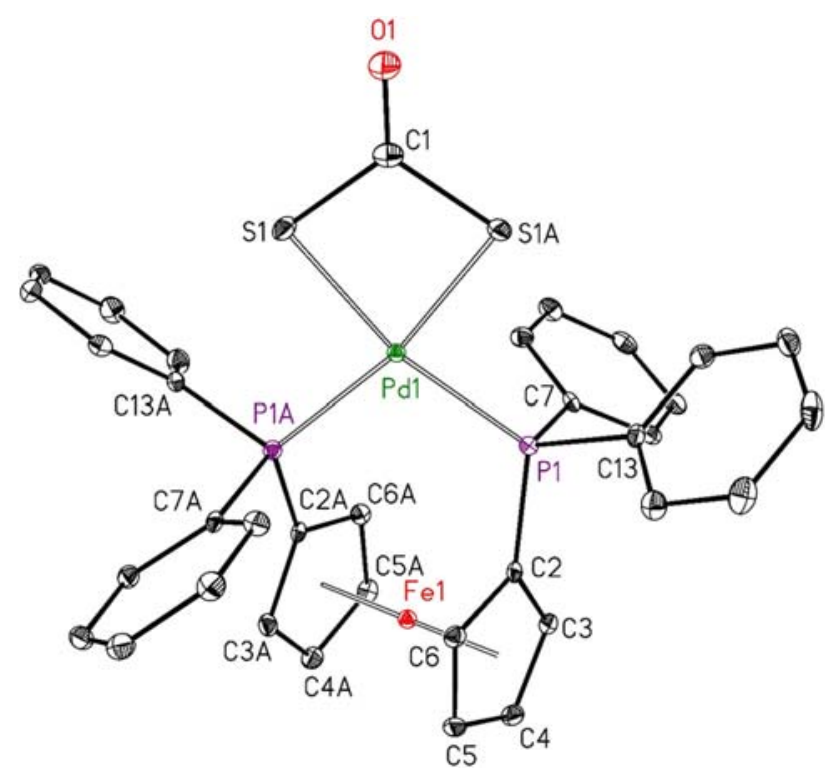

Figure 2. Molecular structure and atom labelling scheme of 2 . The ellipsoids represent a probability of $30 \%, \mathrm{H}$ atoms are omitted for clarity reasons.

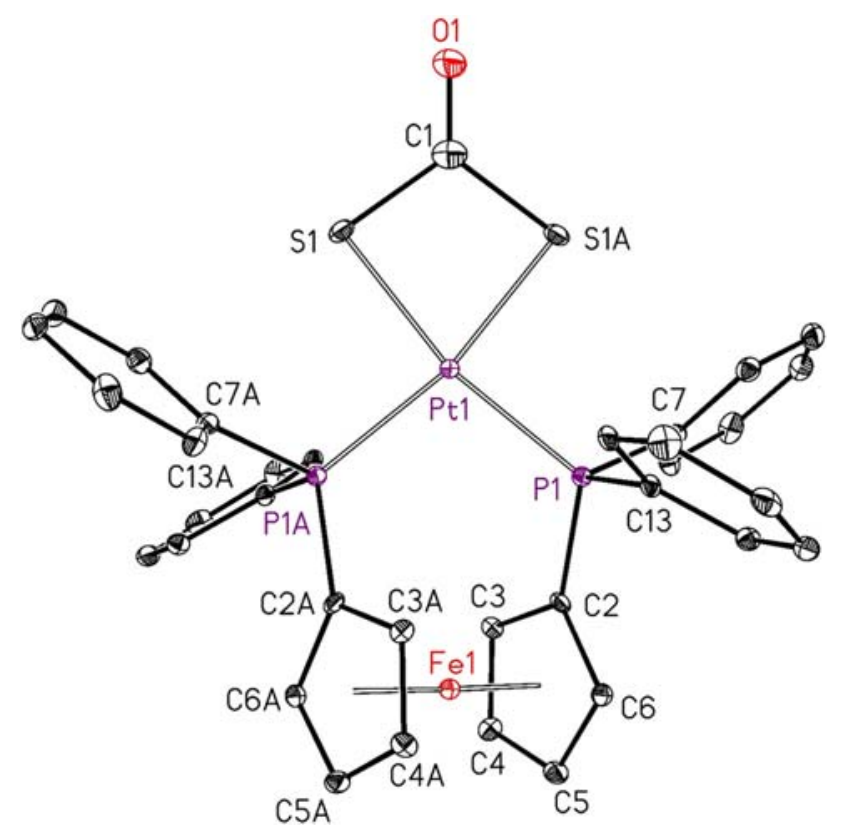

Figure 3. Molecular structure and atom labelling scheme of 3. The ellipsoids represent a probability of $30 \%, \mathrm{H}$ atoms are omitted for clarity reasons.

Pt-P (2.2825(10) $\AA$ ) bond distances of $\mathbf{3}$ are comparable to the corresponding distances of $\mathrm{Pt}\left(\kappa^{2} S, S-\mathrm{S}_{2} \mathrm{CO}\right)\left(\mathrm{PPh}_{3}\right)_{2}$ and $\mathrm{Pt}\left(\kappa^{2} S, S-\mathrm{S}{ }_{2} \mathrm{CO}\right)\left(\kappa^{2} P, P-\left(\mathrm{Ph}_{2} \mathrm{PC}_{2} \mathrm{H}_{4} \mathrm{PPh}_{2}\right) .{ }^{40}\right.$

The $\mathrm{S}-\mathrm{C}$ bond lengths of the three complexes (1.768(3)-1.802(3) ̊) are comparable to each other and to those reported for similar systems. ${ }^{40-42}$ While the $\mathrm{C}-\mathrm{O}$ bond of the dithiocarbonato ligand in each of complexes 1-3 is a typical carbon-oxygen double bond and found within the range of those reported for dithiocarbonato complexes. ${ }^{40-42}$ 
Table 2. Selected bond lengths and angles of 1, 2 and $\mathbf{3}$.

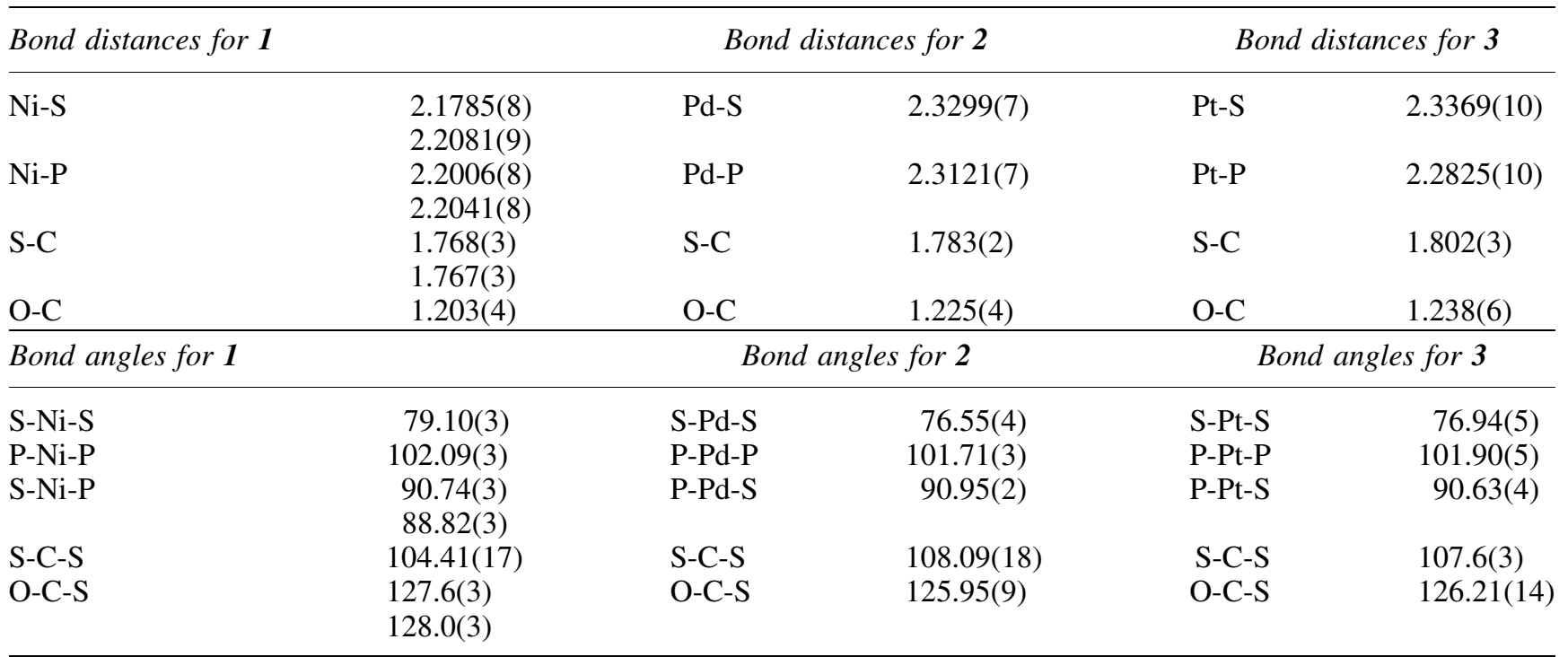

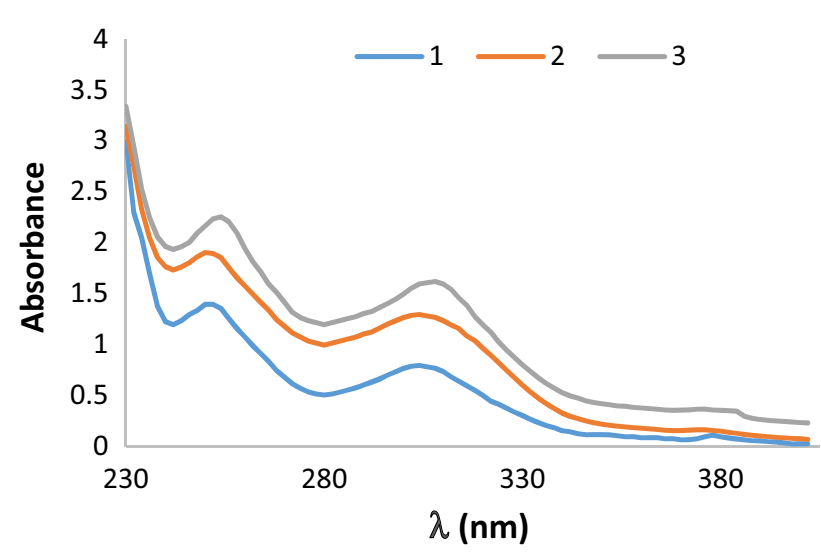

Figure 4. UV-Vis absorption spectra of $1.0 \times 10^{-4} \mathrm{M}$ 1-3 in $\mathrm{CH}_{2} \mathrm{Cl}_{2}$ using $1 \mathrm{~cm}$ path length.

The S-M-S, P-M-P and S-M-P angles indicate a distorted square planar geometry around the metal center. Among these, the smallest angle is the S-M-S angle imposed by the four-membered ring of the ligand, while the P-M-P angle is the largest also imposed by the high steric dppf ligand. The S-C-O and S-C-S bond angles are around $120^{\circ}$ indicating a planar dithiocarbonato ligand with $\mathrm{sp}^{2}$ hybridized carbon. As expected, the S-C-S angle is compressed as it is part of the fourmembered ring leaving the two $\mathrm{S}-\mathrm{C}-\mathrm{O}$ angles to expand.

\subsection{UV-visible spectroscopy of complexes 1-3}

The electronic absorption spectra of the complexes 13 were recorded in dichloromethane solution and are shown in Figure 4. The UV-Vis spectra of the $\mathrm{MS}_{2} \mathrm{P}_{2}$ chromophores showed a strong absorption (252-256 $\mathrm{nm}$ ) which is assigned to $\mathrm{M}$ (II) $\rightarrow \mathrm{L}$ (MLCT) transition. ${ }^{24}$ The other medium absorption band (300-308 $\mathrm{nm})$ can be assigned either to intra-ligand transitions in the $\mathrm{S}_{2} \mathrm{CO}$ group ${ }^{24}$ or to a metal d-d transition. ${ }^{38}$ The very weak band (378-380 $\mathrm{nm}$ ) may be assigned for a $\mathrm{d}-\mathrm{d}$ transition of the ferrocene moiety as indicated for similar systems (dppf)PtL ( $\mathrm{L}=1,3$-dithiole-2-thione4,5-dithiolate, 5,6-dihydro-1,4-dithiin-2,3-dithiolate, 6-hydro-5-phenyl-1,4-dithiin-2,3-dithiolate, 5,6-diphenyl-1,4-dithiin-2,3-dithiolate, 1,2-bis(methylthio)ethylene-1,2-dithiolate, 2,2-dicyano-1,1-ethylenedithiolate). ${ }^{38,43}$

\section{Conclusions}

The dithiocarbonato complexes 1-3 were obtained by $\mathrm{C}-\mathrm{O}$ bond cleavage of the corresponding $\mathrm{O}$ ethyldithiocarbonato metal intermediates. The complexes are fully characterized by spectroscopic techniques (UV-Vis, IR, ${ }^{1} \mathrm{H}-,{ }^{13} \mathrm{C}\left\{{ }^{1} \mathrm{H}\right\}-,{ }^{31} \mathrm{P}\left\{{ }^{1} \mathrm{H}\right\}-\mathrm{NMR}$ ) and elemental analysis. The structures of these complexes showed a distorted square planar geometry with the S-M-S bond angle being the smallest and the P-M$\mathrm{P}$ bond angle is the largest.

\section{Acknowledgements}

The financial support from the deanship of scientific research, Jordan University of Science and Technology, Grant Number (468/2018) is greatly acknowledged.

\section{References}

1. Tekink E R and Haiduc I 2005 Stereochemical aspects of metal xanthate complexes: molecular structure and supermolecular assembly Prog. Inorg. Chem. 54127 
2. Reddy P C and Rangamannar B 1996 Comparative substoichiometric extraction and quantification of mercury in geological water samples with potassium salts of ethyl, propyl, butyl, pentyl and benzyl xanthates J. Radioanal. Nucl. Chem. 2139

3. Reddy P C and Rangamannar B 1996 Comparative substoichiometric extraction of silver with potassium salts of ethyl, propyl, butyl, pentyl and benzyl xanthates J. Radioanal. Nucl. Chem. 214159

4. Wolf N and Roundhill D M 1994 Long chain alkyl and choline substituted xanthates as extractants for cadmium(II) Polyhedron 132801

5. Sasidharan K K, Palaty S, Gopalakrishnan K S, George K E and Joseph R 2004 Room temperature prevulcanization of natural rubber latex using xanthates Appl. Poly. Sci. 941164

6. Natarajan K A and Prakasan M R 2013 Biodegradation of sodium isopropyl xanthate by Paenibacillus polymyxa and Pseudomonas putida Mineral Metallurg. Proc. 30226

7. Zelmon D E, Gebeyhu Z, Tomlin D C and Thomas M 1998 Investigation of transition metal-xanthate complexes for nonlinear optical applications Mater. Res. Soc. Symp. Proc. 519395

8. Singh A, Trivedi M, Singh P, Kociok-Köhn G, Azad U P, Singh A K and Kumar A 2018 Copper(I) tertiary phosphine xanthate complexes as single source precursors for copper sulfide and their application in the OER New J. Chem. 4218759

9. Al-Shakban B, Matthews P D, Deogratias G, McNaughter P D, Raftery J, Vitorica-Yrezabal I, Mubofu E B and O'Brien B 2017 Novel Xanthate complexes for the size-controlled synthesis of copper sulfide nanorods Inorg. Chem. 569247

10. Schick H D, Danhauser-Riedl S, Amtmann E, Busch R, Reichert A, Steinhauser G, Rastetter J, Sauer G and Berdel R 1989 Antitumoral activity of a xanthate compound II. Therapeutic studies in murine leukemia and tumor models in vivo Cancer Lett. 46149

11. Friebolin W, Schiling G and Zoeller M 2005 Antitumoral activity of non-platinum xanthate complexes J. Med. Chem. 487925

12. Friebolin W, Schiling G and Zoeller M 2004 Synthesis and structure-activity relationship of novel antitumoral platinum xanthate complexes $J$. Med. Chem. 472256

13. Amtmann E, Zoeller G, Wesch H and Schilling G 2001 Antitumoral activity of a sulfur-containing platinum complex with an acidic $\mathrm{pH}$ optimum Cancer Chemother. Pharmacol. 47461

14. Xiong R G, Liu C M, Li H Z, You X Z and Huang X Y 1996 Bis[O-(4-methylcyclo-hexyl) di-thiocarbonatoS,S']nickel(II) Acta Crystallogr. Sect. C: Cryst. Struct. Commun. 52519

15. Cox M J and Tickink E 1999 The crystal and molecular structures of some nickel(II)bis(O-alkyl-dithiocarbonate)s and nickel(II)bis(N,N-dialkyldithiocarbamate)s: An evaluation of the coordination potential of 1,1dithiolate ligands in their nickel(II) complexes Z. Krystallog. 214242

16. Rajnák C, Moncol J, Boča R, Titiš J and Varga F 2018 Diamagnetic cobalt(III)tris $(O$-ethylxanthate) and nickel(II)bis(O-ethylxanthate) Nov. Biotechnol. Chim. 16138
17. Tan Y S, Abdul Halim S M, Molloy K C, Sudlow A, Otero-de-la-Roza A and Tickink E 2016 Persistence of $\mathrm{C}-\mathrm{H} . . . \pi$ (chelate ring) interactions in the crystal structures of palladium bis(O-alkyldithiocarbonate $) \mathrm{s}, \operatorname{Pd}\left(\mathrm{S}_{2-}\right.$ $\mathrm{COR})_{2}$. The utility of $\mathrm{Pd}\left(\mathrm{S}_{2} \mathrm{COR}\right)_{2}$ as precursors for palladium sulfide materials CrystEngComm 181105

18. Kumar G, Kumar R, Ogric-Ildiz C and Fausto R 2019 Structure, spectroscopic and catalytic activity for peroxide ring-opening of nickel methylxanthate $\mathrm{J}$. Mol. Struct. 177733

19. Juncal L C, Avila J, Asensio M C, Vedova C O D and Ramo R M 2017 Electronic structure determination using an assembly of conventional and synchrotron techniques: the case of a xanthate complex J. Chim. Acta A: Mol. Biomol. Spec. 180183

20. Tiekink E and Winter G 1986 The crystal-structure of bis $(O$-ethylxanthato)-triphenylphosphinenickel(II)$\mathrm{Ni}\left(\mathrm{S}_{2} \mathrm{COC}_{2} \mathrm{H}_{5}\right)_{2} \mathrm{P}\left(\mathrm{C}_{6} \mathrm{H}_{5}\right)_{3}$ Aus. J. Chem. 39813

21. Manohar A, Karpagavel K and Arumugam M 2014 Chelated and free phosphine adducts of nickel(II)dithiocarbamates: synthesis, spectroscopy and valence bond parameter calculations Int. J. ChemTech. Res. 6474

22. Perpiñán MF, Ballester L, González-Casso ME and Santos A 1987 Reactions between bis $O$-alkyldithiocarbonato)nickel(1l) complexes and phosphines. Formation of a dithiocarbonate complex of nickel(11): $\left[\mathrm{Ni}\left(\mathrm{S}_{2} \mathrm{CO}\right)\left(\mathrm{Ph}_{2}\right.\right.$ $\left.\mathrm{PCH}_{2} \mathrm{CH}_{2} \mathrm{PPh}_{2}\right)$ ] J. Chem. Soc., Dalton Trans. 281

23. Haiduc I, Semeniuc R F, Campian M, Kravtsov V C, Simonov Y A and Lipkowski J 2003 The reaction of nickel(II) xanthates with tetraphenyldiphosphinoethane (dppe) revisited. Formation and crystal structures of $\mathrm{Ni}_{3} \mathrm{~S}_{2}\left(\mathrm{~S}_{2} \mathrm{COR}\right)_{2}($ dppe $) \quad\left(\mathrm{R}=\mathrm{Me}\right.$, Et; dppe $=\mathrm{Ph}_{2} \mathrm{PCH}_{2-}$ $\left.\mathrm{CH}_{2} \mathrm{PPh}_{2}\right)$ at room temperature and of $\mathrm{Ni}\left(\mathrm{S}_{2} \mathrm{CO}\right)$ (dppe) at $150 \mathrm{~K}$ Polyhedron 222895

24. Trávníček Z, Pastorek R, Šindelář Z, Klička R and Marek J 1996 Investigation of \{1,2-bis(diphenylphosphino) ethane-P,P' \}-(dithio-carbonato-S,S')-nickel(II) Trans. Met. Chem. 2181

25. Tenorio M J, Puerta M C and Valerga P 1996 Nickel complexes of 1,2-bis(diisopropylphosphino)ethane with sulfur-containing ligands J. Chem. Soc., Dalton Trans. 1935

26. Colton R and Tedesco V 1991 Multinuclear $\left({ }^{31} \mathrm{P},{ }^{77} \mathrm{Se}\right.$,

${ }^{195} \mathrm{Pt}$ ) magnetic resonance studies on the interaction of platinum bis(n-propylxanthate) with potentially bidentate ligands Inorg. Chim. Acta 183161

27. Fackler J P Jr. and Seidel W C 1969 Sulfur ligand complexes. IX Reactions of metal xanthates and their derivatives. The formation of bisphosphine-bithiocarbonate and -trithiocarbonate complexes of palladium(II) and platinum(II) Inorg. Chem. 81631

28. Casollat U, Ajo D, Valle G, Corain B, Longato B and Graziani R 1988 Heteropolymetallic complexes of 1,1'bis(diphenylphosphino)ferrocene (dppf). II. Crystal structure of dppf and $\mathrm{NiCl}_{2}$ (dppf) J. Chem. Cryst. 18583

29. Hayashi T, Konishi M, Kobori Y, Kumada M, Higuchi T and Hirotsu K 1984 Dichloro [1,l'-bis(diphenylphosphino)ferrocene]palladium(II): an effective catalyst for cross-coupling of secondary and primary alkyl Grignard and alkylzinc reagents with organic halides $J$. Am. Chem. Soc. 106158

30. Colacot T J, Teichman, R A, Cea-Olivares R, Alvarado-Rodrigues J G, Toscano R A and Boyko W 1998 
Synthesis, single crystal $\mathrm{X}$-ray structure determination and NMR studies of $\mathrm{Cp}_{2} \mathrm{Fe}\left(\mathrm{PPh}_{2}\right)_{2} \mathrm{PtPh}_{2}$ and $\mathrm{Cp}_{2}$ $\mathrm{Fe}\left(\mathrm{PPh}_{2}\right)_{2} \mathrm{PtI}_{2}$ J. Organomet. Chem. 557169

31. Nonius BV COLLECT, Data Collection Software; Netherlands, 1998

32. Otwinowski Z and Minor W 1997 Processing of X-ray diffraction data collected in oscillation mode In Macromolecular Crystallography Part A C W and R M Sweet (Eds.) Methods Enzymol. 276307

33. SADABS 2.10, Bruker-AXS inc, 2002, Madison, WI, USA

34. Sheldrick G M 2008 Acta Cryst. A64 112

35. XP, Siemens Analytical X-ray Instruments Inc, 1990, Karlsruhe, Germany; 1994; Madison, WI, USA.

36. Al-Jibori S A, Khaleel T F, Ahmed S A O, AlHayaly L G, Merzweier K, Wagner C and Hogarth G 2012 Heteroleptic palladium(II) and platinum(II) complexes of 1,1-bis(diphenylphosphino)ferrocene (dppf) and heterocyclic thionates: crystal structures of $\left[\mathrm{Pt}(\mathrm{Phoz})_{2}\left(\kappa^{2}-\mathrm{dppf}\right)\right] \quad(\mathrm{PhazH}=5$-phenyl-1,3,4-oxadiazole-2-thione) and $\left[\mathrm{Pd}(\mathrm{bzoxt})_{2}\left(\kappa^{2}\right.\right.$-dppf) (bzoxt= benz1,1-oxazoline-2-thione) Polyhedron 420

37. Aucott S M, Milton H M, Robertson S D, Slawin A M Z, Walker G D and Woollins J D 2004 Platinum complexes of naphthalene-1,8-dichalcogen and related polyaromatic hydrocarbon ligand Chem. Eur. J. 10166

38. Nataro C and Fosbenner S M 2009 Synthesis and characterization of transition-metal complexes containing 1,1'-bis(diphenylphosphino)ferrocene J. Chem. Ed. 861412

39. Noh D-Y, Seo E-M, Lee H-J, Jang M G, Choi M G, Kim Y H and Hong J 2001 Syntheses and characterization of heterobimetallic complexes (dppf)Pt(dithiolate) (dppf: bis(diphenylphosphino)ferrocene); X-ray crystal structures of (dppf)PtL where $\mathrm{L}=\mathrm{dmit}$, phdt and i-mnt Polyhedron 201939

40. Lin I J B, Chen H W and Fickler J P Jr. 1978 Sulfur Chelates. 32. Studies of the solid-state molecular structure and solution structures and dynamics of bis(phosphine) adducts of platinum(1I) 1,1-dithiolates. Molecular structures of $\mathrm{Pt}\left[\mathrm{S}_{2} \mathrm{CN}(\mathrm{i}-\mathrm{Bu})_{2}\right]_{2}\left(\mathrm{PMe}_{2} \mathrm{Ph}\right)_{2}$, $\mathrm{Pt}\left(\mathrm{S}_{2} \mathrm{CO}\right)\left(\mathrm{PPh}_{3}\right)_{2}$, and $\mathrm{Pt}\left(\mathrm{S}_{2} \mathrm{CO}\right)($ diphos $) 1 / 4 \mathrm{CHCl}_{3}$ Inorg. Chem. 17394

41. Jones P G and Sheldrick G M 1983 Dithiocarbonate and trithiocarbonate complexes of palladium(II); crystal structure of $\mathrm{Pd}\left(\mathrm{Ph}_{3} \mathrm{P}\right)_{2}\left(\mathrm{CS}_{2} \mathrm{O}\right) \cdot \mathrm{CH}_{2} \mathrm{Cl}_{2}$ Z. Naturforsch. 38B 449

42. Keter F K, Guzei I L and Darkwa G 2013 N-heterocyclic dithiocarbamate platinum(II) complexes: Unexpected transformation of dithiocarbamate to oxodithiocarbonate in phosphinoplatinum complexes in solution Inorg. Chem. Comm. 2760

43. Zagal J and Costamagna J A 1977 Complexes of tri-nbutylphosphine and xanthates nickel(II) Inorg. Nucl. Chem. Lett. 13411 